\title{
Teaching for Creativity: Mini-c, Little-c and Experiential Learning in College Classroom ${ }^{1}$
}

\begin{abstract}
The wave of changes in teaching approaches due to the introduction of the 21 century skills - including creativity and problem solving - has affected not only $\mathrm{K}$ through 12 classrooms, but also colleges and universities. Thompson (2014) suggests that when designing courses and curricula college educators should consider not only the content knowledge, skills and dispositions their students need to learn, but also what capacities ought to be developed and through what type of pedagogies. In this article, I propose that pedagogies of engagement are developed and used to teach content and skills in a college level course on Psychology of Creativity. In the main section of the article, I present three groups of creative assignments developed in collaboration with Dr. Heather Snyder: journal activities, creative project assignments, and creative problem-solving workshops. I argue that these assignments not only affect students' motivation, engagement, and deep learning, but they also facilitate the development of mini-c and little-c creativity.
\end{abstract}

Keywords: creativity, mini-c, little-c, education, experiential learning, pedagogy.

\section{Nauczanie dla twórczości: Rozwijanie kreatywności poprzez doświadczenie w tworzeniu wśród studentów psychologii i innych kierunków}

\begin{abstract}
Abstrakt
Przemiany w pedagogice wywołane wprowadzeniem tak zwanych umiejętności XXI wieku wywarły wpływ na nauczanie na poziomie od podstawowego po wyższe. Zgodnie z tym, co pisze Thompson (2014), nauczyciele akademiccy planujący kursy
\end{abstract}

\footnotetext{
* Center for Values in Medicine, Science, and Technology, The University of Texas at Dallas.

1 Author's Note. I would like to thank my colleague and friend, Dr. Heather T. Snyder, for her support in the process of implementing and designing the creative activities and assignments presented in this article. This process is an ongoing effort of ours to improve our students' education and learning outcomes.
} 
i programy nauczania powinni odpowiednio dostosować podejście metodyczne, aby takie umiejętności skutecznie rozwijać. W niniejszym artykule proponuję, aby do nauczania wiedzy i umiejętności z zakresu psychologii twórczości wykorzystać podejście zwane pedagogikq zaangażowania (por. z kształceniem podmiotowym, Stasiak 2005). Celem tego podejścia jest rozwój umiejętności twórczych oraz umiejętności skutecznego i głębokiego uczenia się poprzez zaangażowanie, rozwijanie motywacji oraz tworzenie. Główna część artykułu poświęcona jest opisowi trzech grup zadań zaprojektowanych na potrzeby kursu Psychologia Twórczości, przy współpracy Dr Heather Snyder. Zadania te obejmują prowadzenie dziennika, zadania związane $\mathrm{z}$ twórczym projektem oraz warsztaty twórczego rozwiązywania problemów. W dalszej części artykułu staram się pokazać, że te zadania - odpowiadające założeniom pedagogiki zaangażowania - nie tylko ułatwiają przyswajanie wiedzy i umiejętności akademickich, ale przede wszystkim rozwijają kreatywność na poziomie płynnym i skrystalizowanym.

Słowa kluczowe: kreatywność, mini-c, little-c, edukacja, nauczanie, uczenie przez doświadczenie.

\section{Introduction}

In August 2010 I participated in my first American Psychological Association Convention. One of the sessions I attended was devoted to the teaching psychology of creativity. There I met my dear colleague and friend, Dr. Heather Snyder, now professor of psychology at Edinboro University in Pennsylvania. During the session, Dr. Snyder shared her experiences not with what to teach the young adepts of creativity, but how to do it effectively. At that time, I had only begun teaching the Psychology of Creativity course at the University of Texas at Dallas. And my beginnings had been very humble, to say the least. I had offered a survey course in Psychology of Creativity, delivered mostly as a series of interactive lectures, and with a handful of creative exercises and demonstrations sprinkled here and there. If a mini-c or little-c creativity moment happened, it was sporadic; I'd been more focused on dispensing knowledge about my beloved psychology of creativity than on systematic attempts to develop and hone little-c creativity in my students. In the end, neither I nor my students had been really satisfied with the outcomes of my course. Dr. Snyder's presentation was a wake-up call and turning point all in one. It was high time I walked the walk, and finally focused on developing mini-c and little$\mathrm{c}$ in my students.

After the conference, I contacted Heather and several emails later, we decided to... teach that course in tandem. We streamlined its content, decided upon the reading materials, and adapted the activities Heather initially developed for her students at Edinboro University, and incorporated our teaching practices into a larger pedagogical intervention study on the effectiveness of assignments and 
activities we use in our classrooms and on their impact on students' creativity (some if the results have been reported in Snyder, Grohman, Tomlinson, Payette 2012).

The main goal of this article is to share with the reader the kinds of creative activities and assignments we use in our Psychology of Creativity courses as well as the practical pedagogy behind them, such that any university professor can modify those assignments and activities to benefit teaching and learning processes in their classrooms. The article starts with a short summary of changes in the scope and goals of today's higher education to demonstrate where our course fits into this larger educational context. In the subsequent sections, I describe the what, the how, and the why of the Psychology of Creativity course, and wherever applicable, I provide references to empirical and theoretical studies we used to develop our creative assignments and activities.

\section{Pedagogies of Engagement in $21^{\text {st }}$ Century Higher Education}

Most of the experts in higher education agree that universities and colleges should reformulate their goals and focus less on dispensing information and more on developing students into mature adults, who not only possess domain-relevant knowledge, but who are also capable of functioning in a complex society, and who are prepared for the next phase of their studies or career (Pianta 2017; Garson Jr., Pianta 2017; see also Grohman, Szmidt 2013). Therefore, following Robert Thompson's advice, the educator ought to consider the following questions when designing curricula and courses: (1) What foundation of knowledge, skills, and dispositions will students need?, (2) How can these capacities be developed?, (3) What corresponding changes are needed in educational practices to foster the development of these capacities? (Thompson 2014). At the first glance, there's nothing new about the answer to the first question. After all, figuring out the content of the given course is bread and butter for every teacher, university teacher notwithstanding. What is less obvious, however, is figuring out the right proportion of content knowledge to skills on the one hand, and the different types of skills on the other hand.

Let's take the psychology of creativity as an example. I imagine most of us can agree that a successful course in this area should include broad concepts such as cognition, cultural context, self-improvement, and education. The question remains, what types of skills should our students actually learn? Traditional approach to college education suggests focusing on academic skills, such as critical thinking, understanding and application of learned concepts, and oral and written communication. Teaching these skills does not necessarily require designing specific assignments - a test, a paper, and an oral presentation will do. However, incorporating any of the $21^{\text {st }}$ century skills (see Partnership for $21^{\text {st }}$ Century Skills, 2008; 
www.p21.org), such as developing life-long learning, and innovative, creative thinking, and creative problem-solving skills actually requires quite substantial changes in pedagogy, both from the perspective of the mechanics of teaching and expectations towards students and teachers.

This brings us to Thompson's second and third questions: What kind of pedagogical approach will help us turn our students into life-long, creative, innovative learners and what educational practices need to be changed or modified? Some educators postulate embracing the Deweyan progressive education movement that focuses on linking experience with reflection and understanding with doing (Dewey 1933, 1938). Others call such an approach the pedagogies of engagement (Edgerton 1997). Whatever the label, it seems that such approaches postulate moving away from didactic, lecture-based pedagogies - teaching as telling; learning as recall - to pedagogies that on the one hand embrace student engagement, and on the other hand direct students' experience with methods and processes of inquiry and experiential, problem-based learning. To answer Thompson's third question, the major shift in teaching practice within pedagogies of engagement requires a redefinition of teachers' and students' roles in the classroom. Since the pedagogies of engagement postulate that teachers are no longer dispensers of knowledge, facts, and information, their role becomes that of facilitators of learning who help students to stay engaged and to hone their self-regulation, deliberate practice, and deep learning skills (Hodges 2015; Lang 2015). And as far as students are concerned, to fully benefit from facilitated learning experience, they need to change their classroom normative behaviors from merely demonstrating civil attention during lectures (cf. Howard 2015), to being responsible for their learning by taking initiative, making decisions, investigating, and being accountable for the results (Itin 1999; Schneider 2009). It seems then, that the pedagogies of engagement implemented in a university classroom have at least three advantages over the more traditional teaching and learning approach. First, they put emphasis on student-centered learning environment; second, they equally concentrate on content-related and content-independent learning skills.

The third advantage is that such pedagogies seem to work well with the diverse body of university students. What does this diversity mean? In most of the American state universities - The University of Texas at Dallas is a good example - this diversity manifests itself in at least 3 major ways. First, many of my students have racially and ethnically diverse backgrounds coupled with diverse family values (from children of overprotective parents to independent, fulltime working non-traditional students). Second, there's also a hard to ignore intellectual diversity. For example, only half of my students are in fact psychology students. The other half represent such areas of concentration as accounting, business, arts \& technology, emerging media communications, arts \& humanities, and natural sciences. In addition to that, in any given semester, I teach students who have already taken at least three advanced courses in psychology, as well as those who 
have never taken an introductory Psychology 101, and whose knowledge about psychological phenomena consists of a collection of colorful myths and misconceptions. And third, I have to simply acknowledge that not all of my students want to learn what I teach. The Psychology of Creativity course, or psychology as a whole, can be a fascinating discipline to me, but not necessarily to the majority of my students! Eric Mazur, a physics professor, once said “(...) if you have students who want to learn, you can do whatever you want, it doesn't matter as long as you give them sources of knowledge" (as cited in Huston 2009: 165). In other words, if we only had most motivated students in our courses, we could remain mere knowledge dispensers through traditional lectures. But, working with diverse body of students requires careful consideration of what it is that students learn, and how they learn it. The pedagogies of engagement approach have given Dr. Heather Snyder and me a useful framework for the Psychology of Creativity course that allowed is to teach about and for creativity through engagement in experiential learning.

\section{Teaching for Creativity through Experiential Learning: The Psychology of Creativity Course}

In the area of creativity and education, the pedagogies of engagement seem to be reflected in the combination of teaching creatively and teaching for creativity approaches proposed by Jeffrey and Craft (2014). While teaching creatively means applying imaginative approaches to increase the effectiveness of learning, teaching for creativity focuses on forming attitudes towards creativity, and on developing students' creative thinking skills and behavior. Each approach adds a valuable component to students' education. By developing materials and activities that motivate students to learn, teaching creatively impacts the level of ownership and control in the learning process and innovation in thinking. The concept of teaching for creativity, on the other hand, focuses on encouraging students to believe in their creative identity and creative abilities, and on fostering creativity by curiosity and "learner inclusive" pedagogy, where the learner is encouraged to engage in identifying and exploring knowledge (Jeffrey, Craft 2004).

At the core of teaching for creativity lies the development of a creative attitude through impacting thinking patterns about one's creativity, through evoking positive affect, motivation and engagement, and through active engagement in creativity (Grohman, Szmidt 2013). All three components of creative attitude enable development of creativity not only at the level of mini-c insights, but also at the more involving little-c level that requires application of knowledge to solve open-ended and ill-defined problems (Kauman, Beghetto 2009; Nęcka 2001). The Psychology of Creativity course has been designed to provide ample opportunities to shape students' creative attitudes through carefully crafted mini-c and little-c creativity experiences. In the subsequent sections, I present a short summary of the 
content of the Psychology of Creativity course (the What), as well as a thorough description of the assignments and activities through which the course content is taught (the How).

\section{The What: Content and Learning Objectives}

The Psychology of Creativity is an upper-level elective course offered to university juniors and seniors, that is to $3^{\text {rd }}$ and $4^{\text {th }}$ year students representing various areas of concentration. Hence, rather than focusing on highly specialized issues within psychology of creativity, the Psychology of Creativity is a survey course, with coordinated with the 2012 edition of the textbook by R. Keith Sawyer Explaining Creativity. The Science of Innovation. The main thematical units are grouped into four main areas: 1) definitions and measurement of creativity, including the person, product, process, press framework; 2) creativity from the individualistic perspective (cognition, motivation, personality, human development, biological basis, mental health); 3) creativity from the sociocultural perspective (family, groups, organizations, cultures, ethics); 4) creativity from the perspective of education and enhancement. Each thematical unit introduces specific creativity concepts that become the focus of particular lessons. Some of the specific concepts are included in the list below:

- Four-C Model of creativity

- Problem finding vs. Problem solving

- Associations, conceptual combinations, metaphors and analogies in the creative process

- Incubation and Insight in the creative process
- Intrinsic and extrinsic motivation

- Passion

- Family factors that relate to creativity

- Mental health and creativity

- Individual vs. Group creativity

- Ethics and creativity

- Creativity as cultural participation

To keep students interested and engaged - especially those who do not have much background in psychology - we often start learning about a given concept by sharing our beliefs about it. For example, when introducing the topic of mental health and creativity, my students start with sharing their observations that "many poets or creative writers or visual artists are mentally ill". Such an exchange of various beliefs gives students an opportunity to examine their misconceptions about creativity and construct new, more refined meanings. Also, sharing those initial beliefs, gives us the launching point, from which we can examine the existing psychological evidence and psychological theories that aim at seeking a link between a given concept and creativity. 
Apart from content knowledge, students in our courses have an opportunity to develop specific academic skills as well as skills related to creativeness, such as problem finding, generation and combination of ideas, evaluation of ideas, and communication of ideas. The students learn those skills through carefully crafted assignments and activities completed at home and in the classroom. The content knowledge and related learning objectives - describing and explaining concepts, analyzing and identifying theoretical and methodological approaches, applying concepts to real-life situations, and solving problems creatively - are assessed through both traditional and creative assessment activities, some of which are described below.

\section{The How: Experience and Reflection, Understanding and Doing}

With our diverse groups of students in mind, Dr. Snyder and I have introduced specific assignments, whose objectives were on the one hand to guide students' learning and reflection on major concepts taught throughout the semester, and on the other hand to provide experiential learning geared toward creativity enhancement. The development of the assignments was based on the assumption that students' positive experiences with learning have an impact not only on their satisfaction from the course, but also on their learning outcomes (e.g., Pekrun, Goetz, Titz, \& Perry 2002; Yoder, Hochevar 2005). Some research demonstrated that such positive impact was specifically observed when students perceived course assignments as interesting and engaging (Malouff, Hall, Schutte, \& Rooke 2010). The creative assignments described herein fulfil both the "engagement" and "creativeness" requirements by including tasks that are new to the student and/or teacher, and appropriate for the course (see Snyder 2013 for a brief review of creative assignments and their benefits).

\section{Journal Assignments}

According to studies in the area of teaching psychology, journal assignments are often used to promote students' reflection about the course content; they may also require students to apply course concepts to themselves (e.g., Miller 1997). Journal assignments may also include novel tasks, such as applying personality theories to media examples (Connor-Greene 2000) or include art projects (e.g., Mills 2008). Mills (2008) suggested that one way to increase student engagement with journal assignments (and potentially reduce the "nuisance" response) is to make them active and practical. Therefore, the journal assignments designed for the Psychology of Creativity course attempted to focus students' attention on interesting and personally meaningful aspects of the tasks, as well as to enable the mini-c insights (cf. Beghetto, Kaufman 2010). These assignments are designed to illustrate course 
concepts before they are discussed in class. In other words, their goal is to help students to think about course material in a concrete way, and to apply a given course concept to their own work by showing practical everyday examples of course concepts "in action". For example, before we start discussing various evidence related to mental illness and creativity, students complete the following journal assignment at home:

Entry \#7: While playing music that you do not like at a loud volume, write a poem or very short story with the title "2983". (note: time yourself; stop after 5 minutes!). After completing your writing, on the next page, consider and respond to the following questions:

1) Which song(s) did you listen to for this assignment? Identify the song(s) and artist(s).

2) Did you find this assignment to be easy or difficult to do? How so?

3) Do you think your product is creative? Why or why not?

So, in this assignment students not only have the chance to create a piece of poetry or write a short story, but they also learn to recognize and reflect on various emotions, their intensity, and their role during creative process. The students' observations and reflections are then used as the means to introduce the intricate and nuanced research into mental illness and creativity connection.

When it comes to learning objectives, journal assignments facilitate students' practice of synthesis, critical analysis, and application. In addition to allowing them to take an active role as learners, the journal also provides students with a record of their learning and growth over time (see Table 1 in the Annex for more journal assignment).

\section{Creative Project}

Generally speaking, creative assignments, which serve as term projects, require students to work with the course content in a non-traditional way. For example, students may be instructed to write poetry to enhance empathy in abnormal psychology courses (Connor-Greene, Young, Paul, Murdoch 2005) or to redesign "poorly designed" everyday objects to experience human factors psychology in practice (Carkenord 1994). These types of assignments are typically used to assess the depth of understanding of a given course concept as well as its application in a given context. The creative project designed for our course has been inspired by Sternberg and Dess' (2001) tasks that required application of theory and research to eminent creators, by Connor-Greene and colleagues' (2005) poetry assignment, and by Domino and Wechter's (1976) creative product (for details see Table 2 in the Annex). 
So, what do the students have to do? First, the students choose an artist/ scientist/inventor they would like to focus on in their course project. They are instructed to carefully consider their choices and focus on a Big-C creator for whom biographical or autobiographical information can be easily obtained. For that reason, we further suggest that students focus on creators from $19^{\text {th }}$ and $20^{\text {th }}$ centuries; choosing a contemporary creator often becomes problematic, mainly because of the scarcity of vetted biographical information. Out of many choices my students have made over the years, some favorites include: Björk, Nikola Tesla, Elon Musk, Eminem, Vincent van Gogh, Sylvia Plath, Maya Angelou, Caravaggio, Steve Jobs, David Bowie...and many more. Second, the students need to consider four types of creative projects to choose from. They can choose to write and design a children's book, comic strip, write a poem/lyrics or a creative essay. To ensure a comparable work load, each of these options have a set of minimum requirements to follow, such as number of pages, panels or word count, and so on. Third, while working on the chosen options, students are required to somehow incorporate the course concept and the creator of their choice into their final products. While each option of the creative project assignment provides necessary structure, there is plenty of room for students to take risks and go beyond their comfort zone, and to show their little c-creativity in action. Some students enjoy this risk and delve into the project with energy and zest. However, for others the engagement with such an assignment may cause some level of anxiety, apprehension, and uncertainty. After all, what they likely expect from a typical psychology course is to write a term paper, but not necessarily a poem!

So, to help students go through the process of creating a children's book, a comic strip, a poem, or a creative essay we have incorporated a few structured activities that scaffold students' experience. The students work in small groups on parts of the project in the classroom during carefully designed creative thinking workshops (described in the next section), which guide them through the generation and evaluation of project ideas. In addition to that, students complete two written assignments before embarking on drafting, designing, and writing up their final creative projects. The main goal of the first assignment is to extract information about the chosen creator's path to creativity from biographical material. That is, students need to find out what psychological factors, including immediate social environment like family, mentors, teachers, have likely contributed to that creator's achievements. The psychological factors that have been most often extracted had to do with creative process, personality, family factors, motivation and passion, and with mental health and/or drug and alcohol abuse. This assignment helps students to gather biographical evidence that is later used to support the application of the course concept to a chosen creator.

The second assignment requires the students to apply two psychological concepts we cover during the classes to their chosen creator (compare the list of 
concepts listed earlier). More specifically, students have to demonstrate their understanding of the chosen concepts, the evidence that support them, and the theories that explain them. They also have to show that they can apply those concepts to their creator through discussing the degree to which their chosen creator exemplifies the concept. For example, the empirical evidence linking mental illness to creativity is still far from decisive, but the biographical and autobiographical material on the chosen creator - say a painter - points to the apparent inability to create without their affliction. In such case, students will argue for inconsistency between the existing psychological evidence and the experience and phenomenology demonstrated by a chosen creator. While this assignment helps students to evaluate the usefulness of information and evidence they have gathered on the course concepts and creators, it also prepares them to decide what aspects of the course concepts and what aspects of their chosen creator's life could be successfully translated into one of the four types of creative projects.

Figures 1 and 2 show the examples of two creative projects my students completed this year - the poem on Vincent van Gogh, and the children's book inspired by an Icelandic singer, Björk. These two examples illustrate the ways students use information about their creators of choice, and how they decide to tell a story about the course concept. Typically, the ways the concepts are incorporated range from using explicit labels - e. g. mental illness, flow - to subtle and less obvious presentation through analogies, metaphors, and associations. As far as the creators are concerned, students' creative choices range from re-telling the biography of a creator to the clever use of creators' style (see Fig. 2). In the poetry example (Fig. 1) the student figured out quite an interesting way to discuss Vincent van Gogh's presumed mental illness and its connection to his creativity. She chose to write a poem from the painter's perspective, in which van Gogh is in dialogue with his self-portraits. And it is in this dialogue that we learn about the complex and not so obvious connections between mental illness and creativity. The focal point of the children's book presented in Fig. 2 is the concept of flow. The illustrations and the text used in the book effectively convey what lies at the core of the concept: the experience of distorted sense of time and lack of awareness of bodily needs (hunger). In the book, we see how a little girl, whose appearance is inspired by Björk's aesthetics, gets up in the morning and is immediately drawn to her favorite activity - painting. As the day goes by, she is so engrossed in her creative process, that she forgets to do her homework, chores..., and to eat her lunch. 


\section{"Man On The Canvas"}

I stare away at the starry night with gleaming eyes,

yet what I search for cannot be found above.

In my dreams I lay myself across a field of poignant irises,

yet what I yearn for cannot be pulled from below.

I sit across the many faces with wandering dreams and hopes,

yet what I need cannot so easily be absorbed.

The thoughts linger and the longing returns,

I search for the man on the canvas.

Who is this man that stares blankly at me?

Who is this man that feeds off of me?

This man that pulls you in with eyes that swallow you with no remorse,

a blank stare that speaks a million phrases yet with piercing eyes that shatter my soul.

I step back and reach out for my unfailing absinthe, that clouds away my misery.

This misery that dwells in me for not knowing, who is the man on the canvas.

He sits and stares back at me, and in my warped mind I feel his judgment feed my despair.

My creation, a reflection of myself, yet he bears no resemblance of who I am

I am the lost one, the one that paints to find.

I am the one that looks out towards the fields of wheat with hopes of finding myself,

in which I only see the crows, and I yearn to be like them, free.

I am the one that paints others in seek of myself,

I seek till no end, but I am told that what I search for is split in two.

Just like the voices in my head, that drive the madness within me,

I am the one that paints this man on the canvas longing to know who he is.

With each brush stroke, I find that he is closer to incomplete,

I take another sip, and, in my mind, I know that the man on the canvas is awaiting me.

$\mathrm{Oh}$, if it were so simple, can anyone not see my curse of colors is what sets me free

Why do they confuse the vivid for irrational?

Why confuse purpose with misconception?

$$
\text { Many label me as ill, }
$$

my disease does not lie in a bottle, and it is not that $\mathrm{I}$ am split in two.

It is my curse of colors that brings the eccentric and the truth to light.

It is my internal despair that feeds my curse,

it is the chaos in my head that sheds its vivid insanity on to my canvas.

It is what makes me transcend past my time

Finally, I know who the man on the canvas is,

he awaits silently, awaiting the vivid the real to breathe life unto him.

It is man that yearns to be like me, Van Gogh!

Figure 1. Example of creative project; option: poem; concept: mental illness, alcohol abuse; creator: Vincent Van Gogh; Title: Man On The Canvas. Poem cited with the consent of the student author. 

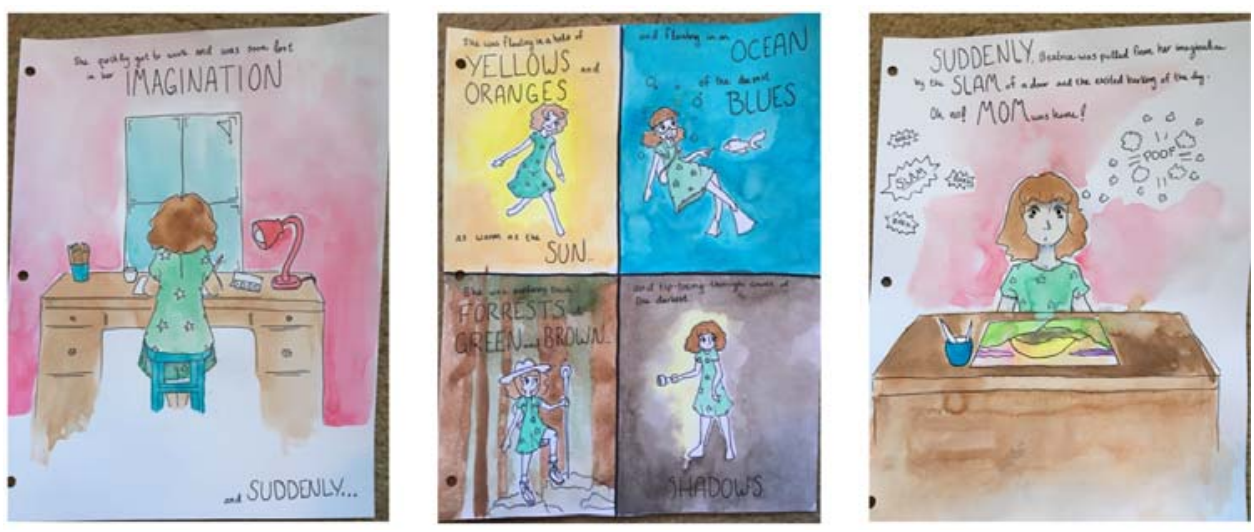

Figure 2. Example of creative project; option: children's book; concept: Flow; creator: Björk. Title: Beatrice Starr's Imagination Adventure. Excerpts cited with the consent of the student author.

\section{Creative Problem-Solving Workshops}

To scaffold students' experiences with their creative projects and also to develop skills related to creative problem solving, Dr. Snyder and I decided to design workshops that would fulfill two goals: first to address a given concept related to creative process, such as problem finding or combination of ideas, and second, to give students the opportunity to apply the learned skill to their creative projects. Altogether, we have developed six activities that engaged students in problem finding, acquiring knowledge, gathering information, generating, combining \& selecting ideas. The activities have been inspired by Creative Problem Solving (Isaksen, Duval, Treffinger 2011) and by an approach to the creative process promoted by R. Keith Sawyer in his book Zig Zag. The surprising path to greater creativity (2013). The workshops are introduced in the first half of the semester, between the third and sixth week, and are coordinated with the first two parts of the creative project assignments described in the previous section (for detailed descriptions see Table 3 in the Annex).

How does it work? The workshop class period starts with a short introduction to the given concepts, and after 30 minutes of lecture, the students are broken down into groups of five to do the workshop activity. To illustrate, let us look at the workshop devoted to problem finding. This workshop is introduced a week before the first part of the creative project - choosing the creator - is due. At this point, the students typically have a very vague idea about the creative project, let alone who they will choose as their central character, and topic they will focus on, and how the project will be delivered. In other words, at this point the project resembles a very open and ill-defined problem that needs to be clarified, restructured, and redefined. To this end, the students participate in an activity called Pick the worst idea 
(adapted from Sawyer 2013). This activity calls for clarifying what the worst possible example of creative project type there could be, that is the worst children's book, the worst comic strip, poem, essay etc. After the students list the characteristics of the worst idea, they are asked to list characteristics of the best or ideal outcome. This activity allows the students to realize that while there are some conventions that could be helpful in framing their creative process, there are some that could not be broken (e.g. a book for young children contains a combination of text and illustration). After the students have finished their activity, we discuss their experience in relation to their creative project and the creative process in general.

\section{The Why? Supporting Mini-c and Little-c Development through Creative Assignments}

To be sure, the creative assignments described above serve as quite effective learning assessment tools that help evaluate basic academic competencies, such as analytical and critical thinking, understanding and application of course concepts, and so on. But, these assessments play also another role: they enable mini-c and little-c creativity development and enhancement. According to Ronald A. Beghetto and James C. Kaufman (2010), the recognition of and encouragement toward mini-c creativity through class activities and assignments lead, on the one hand, to an increase in students' self-efficacy and confidence in their creative potential (cf. Beghetto 2006), and on the other hand - to students' engagement in constructing meanings about creativity - meanings that comply with what is socially and scientifically scrutinized. On top of that, as the authors point out, the mini-c insights enable students to identify the conventions and constraints typical for a given domain.

This, in turn, helps students learn to recognize ideas that fit those conventions and ideas that go beyond them and why. To give an example, most of the journal assignments focus on certain products, like writing a poem or short story, and on connecting students' personal experiences with knowledge they have about given concepts. The mini-c insights the students gain from journal entry \#7: "2983” help them realize the effect emotional states - with their valance and intensity - can have on one's creative process. The plethora of mini-c insights triggered by journal assignments help students to identify the relationship between psychological sciences and their experience and to construct a new, personal meaning of creativity.

Working on creative project assignments adds yet another dimension to experiencing mini-c insights about creativity. By studying psychological concepts that apply to their chosen creators, students learn about scientific conventions of how a given concept is described, researched, and explained. On top of that, they also discover what conventions will help them represent the concepts and creators in 
the most effective way. For instance, one can wonder if drug abuse that almost ruined the career of the famous rapper, Eminem, lends itself to the typical content of children's book. Some students, aware of the conventions of how drug abuse is approached in research (e.g. "drugs impair creativity") and of the convention of the typical children's book (e.g. "positive, happy story") may forgo this option and choose a medium that would allow them to express their knowledge and creativity in a far better way, for example through creative essay. However, if after identifying and examining the conventions, students still want to pursue their original idea, they may need to figure out, which conventions they can break, and which conventions they need to accommodate to.

While the creative problem-solving workshops and journal assignments help students experience a multitude of mini-c insights, the semester-long creative project assignments help nurture their little-c creativity. To successfully complete the projects, the students use their mini-c insights to establish connections between domain-specific knowledge about psychological concepts and their experience with creating (cf. Deweyan understanding and doing and also Grigorenko et al. 2008). To illustrate this, let us go back for a moment to one of our two examples presented earlier - the poem on Vincent van Gogh. The student who worked on this project applied the concept of mental illness and alcohol abuse to Vincent van Gogh. In her response to Creative Assignment 2 (application essay), and subsequently in the poem, she demonstrated sufficient understanding of domain-specific knowledge about the concepts, mainly by referring to many nuances around the mental illness and creativity connection. Through engagement in little-c and creative process - or doing - she discovered how the narrative about her creator and the concepts should be developed to make her project effective. To quote the way she reflected about her process and project in the journal: "Preparation: (...) the concept didn't fit [the children's book]. Illumination (...) decided on a poem instead. It will resonate well with van Gogh's story. Verification: Hopefully the poem explains the concepts I picked"; and "(...) my project conveys what most artists feel: a stigma of being different or mislabeled or confused" (Townsend 2018).

Experiential learning, as manifested in the creative activities and assignments described earlier, has its basis in the cognitive science of learning, which demonstrates that the greater the engagement with the content, the greater retention and transfer; and with better and more effective retention and recall, the deeper and more meaningful the learning (for overview see Lang 2016; Sawyer 2010, 2012). Our students often reported in their final journal comments that they found unusual journal tasks interesting, enjoyable, and useful (Snyder 2010, 2013). The fact that the students commented on enjoyment is an indirect evidence of their motivation to complete these tasks. We have also observed that engagement in a creative project impacted students' task perception. We saw an overall increase of positive emotions related to the bundle of assignments related to the creative project (Snyder et al. 2012). 
The creative assignments used in the Psychology of Creativity course play yet another role in students' learning: they refocus students from performance goals to learning goals, leading to self-improvement self-efficacy, and self-regulation in learning (see Beghetto 2006; Hodges 2015). The assignments and activities also promote establishing meaningful connections between knowledge and personal experiences. In other words, creative assignments enable students to exercise their agency as learners and engage them in deep learning that is socially distributed and situated (Sawyer 2010). Learning and knowing through the creative assignments is a process that includes the community of students, different types of materials they use, and the activities in which knowledge is being applied. During the creative problem-solving workshops, for example, students construct the meaning of the creative process together and reconcile it with their own experiences and individual approaches to creativity.

\section{Final Comments and Conclusions}

Many things have changed in the way I teach and my students learn since the APA convention in August of 2010. As described in previous sections, the creative assignments Dr. Snyder and I have designed and implemented created learning environment conducive for both teaching creatively and teaching for creativity.

The assignments seem also to provide an example of the pedagogical approach Thompson called for in the three questions cited in the introduction to this article. In regards to the issue of the development of students' capacities and educational practices that would foster these capacities, I have demonstrated that the creative assignments - journal entries, creative project assignments, and workshops - provide necessary structure and tools for students to flourish not only academically but also creatively (see also Grohman, Szmidt 2013). First, by recognizing and encouraging the development of mini-c and little-c creativity, journal assignments, workshops and the creative project fit the notion of pedagogies of engagement through pushing students toward finding deeper connections between the concepts they study, other areas of knowledge, hobbies and personal experiences. Second, the experiences gained during work on reflective assignments and the creative project allow for finding personal meaning and application to the students' individual creative processes. Finally, the pedagogies of engagement as exemplified in our creative activities and assignments shift teaching from traditional teacher-centered instructionism to situated, student-centered deep learning (Sawyer 2010, 2012). Instructionism was justified when the objective of education was to effectively prepare students for a foreseeable future in well-defined and well-structured industries. Contrary to that, the pedagogies of engagement aim for "educating graduates that need a deep conceptual understanding of complex concepts and the 
ability to work with them creatively to generate new ideas, theories, products" (Sawyer 2010: 176).

Tatarkiewicz (1982) famously said that creativity is inevitable because every aspect of our lives depends on it - our well-being and our aesthetic experiences, technological advances and discoveries, and fulfillment of societal and individual goals. And indeed, in recent years the value of creativity has been widely recognized in multiple contexts and across various areas of knowledge and achievements (Craft 2011). This sentiment has been reflected not only by educators through the endorsement of the $21^{\text {st }}$ century skills initiative, but also by employers who identify creativity as an attribute they seek in future employees, especially as the workplace changes to require different skill sets from those of previous generations (Association of American Colleges and Universities 2013; World Economic Forum 2016). The course on Psychology of Creativity seems like a perfect candidate to talk the talk about creativity and walk the walk about its complex and fascinating processes. However, implementing creative activities and assignments in any basic or applied course in social sciences will provide necessary space for nurturing both studentcentered learning and creativity.

\section{References}

Association of American Colleges and Universities (2013, April) It takes more than a major: Employer priorities for college learning and student success, http:// www.aacu.org/leap/public_opinion_research.cfm

Beghetto R. A. (2006) Creative Self-Efficacy: Correlates in Middle and Secondary Students, "Creativity Reasearch Journal", 18: 447-457.

Beghetto R. A., Kaufman J. C. (2010) Broadening conceptions of creativity in the classroom in: Nurturing creativity in the classroom, R. A. Beghetto, J. C. Kaufman (eds.), Cambridge University Press: 191-205.

Carkenord D. M. (1994) Promoting human factors psychology thinking through designassignments, "Teaching of Psychology", 21: 235-237.

Cisero C. A. (2006) Does reflective journal writing improve course performance?, "CollegeTeaching", 54: 231-236.

Connor-Greene P. A. (2000) Making connections: Evaluating the effectiveness of journal writing in enhancing student learning, "Teaching of Psychology", 27: 44-46.

Connor-Greene P. A., Young A., Paul C., Murdoch J. W. (2005) Poetry: It's not just for English class anymore, "Teaching of Psychology", 32: 215-221. 
Craft A. (2011) Creativity and education futures. Learning in a Digital Age, Sterling, Trentham.

Dewey J. (1933 [1998]) How we think: a restatement of the relation of reflective thinking to the educative process, Boston, MA: Houghton Mifflin.

Dewey J. (1938) Experience and education, Kappa Delta Pi.

Domino G., Wechter V. T. (1976) Joint teaching of undergraduate courses in creativity, "Teaching of Psychology", 3: 123-127.

Edgerton R. (1997) Education white paper, Unpublished report for the Pew Charitable Trust.

Garson Jr. A., Pianta R. C. (2017, September) Colleges need to be much more innovative with their curricula, https://www.insidehighered.com

Grigorenko E. L., Jarvin L., Tan M., Sternberg R. J. (2008) Something new in the garden: Assessing creativity in academic domains, "Psychology Science Quarterly", 50: 295 -307 .

Grohman M. G., Szmidt K. J. (2013) Teaching for creativity: How to shape creative attitudes and skills in students and teachers in: Teaching creatively and teaching for creativity, M. B. Gregorson, H. T. Snyder, J. C. Kaufman (eds.), New York, NY: Springer Publishing Company: 16-36.

Hodges L. C. (2015) Teaching undergraduate science: A guide overcoming obstacles to student learning, Starling, VA: Sylus Publishing, LLC.

Howard J. R. (2015) Discussion in the college classroom. Getting your students engaged and participating in person and online, San Francisco, CA: Jossey-Bass. A Wiley Brand.

Huston T. (2009) Teaching what you don't know, Cambridge, MA: Harvard University Press.

Itin C. M. (Fall, 1999) Reasserting the philosophy of experiential education as a vehicle for change in the 21st century, "The Journal of Experiential Education", 22: 91-98.

Isaksen S. G., Dorval K. B., Treffinger D. J. (2011) Creative approaches to problem solving. A framework for innovation and change (3rd Edition), SAGE Publications, Inc.

Jeffrey B., Craft A. (2004) Teaching creatively and teaching for creativity: distinctions and relationships, "Educational Studies", 30 (1): 77-87.

Kaufman J. C., Beghetto R. A. (2009) Beyond big and little: The four C model of creativity, "Review of General Psychology", 13: 1-12. 
Lang J. M. (2016) Small teaching. Everyday lessons from the science of learning, San Francisco, CA: Jossey-Bass. A Wiley Brand.

Malouff J. M., Hall L., Schutte N. S., Rooke S. E. (2010) Use of motivational teaching techniques and psychology student satisfaction, "Psychology Learning \& Teaching", 9: 39-44.

Miller S. (1997) Self-knowledge as an outcome of application journal keeping in socialpsychology, "Teaching of Psychology", 24: 124-125.

Mills R. (2008) 'It's just a nuisance': Improving college student reflective journal writing, "College Student Journal”, 42: 684-690.

Nęcka E. (2001) Psychologia Twórczości, Gdańsk, Gdańskie Wydawnictwo Psychologiczne.

Partnership for 21 Century Skills (2008), http://www.p21.org

Pekrun R., Goetz T., Titz W., Perry R. P. (2002) Academic emotions in students'selfregulated learning and achievement: A program of qualitative and quantitative research, "Educational Psychologist", 37: 91-106.

Sawyer R. K. (2010) Learning for creativity in: Nurturing creativity in the classroom, R. A. Beghetto, J. C. Kaufman (eds.), Cambridge University Press: 172-190.

Sawyer R. K. (2012) Explaining Creativity. The Science of Innovation, (2nd edition), Oxford University Press.

Sawyer K. (2013) Zig Zag: The surprising path to greater creativity, CA: Jossey-Bass.

Schneider C. G. (2009) Practicing liberal education: Formative themes in the reinvention of liberal learning, Washington, DC: Association of American Colleges and Universities.

Scott G., Leritz L., Mumford M. (2004) The effectiveness of creativity in training, A quantitative Review, "Creativity Research Journal”, 16: 261-388.

Snyder H. T., Grohman M. G., Tomlinson M., Payette R. (2012, April) Creative selfefficacy and the creative project, Paper presented at APA Annual Convention. Orlando, FL.

Snyder H. T. (2013) Designing creative assignments: Example of journal assignments and a creative project in: Teaching Creatively and Teaching Creativity, M. B. Gregerson, H. T. Snyder, J. C. Kaufman (eds.), NY: Springer Science + Business Media: 163-173. 
Stasiak M. K. (2005) Prawo studenta Wyższej Szkoły Humanistyczno-Ekonomicznej $w$ Łodzi do dodatkowej wolności in: Trening twórczości w szkole wyższej, K. J. Szmidt (red.), Wyższa Szkoła Humanistyczno-Ekonomiczna w Łodzi: 59-80.

Sternberg R. J., Dess N. K. (eds. Special Section) (2001) Creativity, "American Psychologist", 56 (4): 332-362.

Tatarkiewicz W. (1982), Dzieje sześciu pojęć, Wrocław, Ossolineum.

Thompson Jr. R. J. (2014) Beyond reason and tolerance: The purporse of higher education, Oxford, Oxford University Press.

Towsend E. (2018) Journal Entry \#10. Psychology of Creativity, PSY3355, UT Dallas, April 30.

World Economic Forum. (2016, January), The future of jobs, https://www. weforum.org/reports/the-future-of-jobs; (20.03.2018).

Yoder J. D., Hochevar C. M. (2005) Encouraging active learning can improve students' performance on examinations, "Teaching of Psychology", 32 (2): 91-95.

\section{Annex}

Table 1. List of journal entries with complete instructions and requirements.

\section{Journal Assignments}

The journal assignments are a learning tool designed to help you to think about course material in a concrete way, and to apply this material to your own work by showing you practical everyday examples of course concepts "in action." Primarily, the journal will facilitate your practice of course objectives (see page 1 of your syllabus), including synthesis, critical analysis, and application. In addition to allowing you to take an active role in your learning, the journal will also provide you with a record of your learning and your growth over time.

\section{Entry \#1: Discuss the following:}

1) What is creativity?

2) How do you determine whether something is creative? What criteria do you use?

Entry \#2: Draw a picture in your sketchbook that would have the following title: "Hope" After completing the task, on the next page, consider and respond to the following questions:

1) Do you think your response is creative? Why or why not?

2) Do you think this task could be a (good) measure of creativity? Why or why not? 
Entry \#3: For this task, imagine that people no longer needed to sleep. What would happen as a consequence? Write a list that includes original, creative consequences of people no longer needing to sleep. (note: time yourself; stop writing after 3 minutes!)

After completing the task, on the next page, consider and respond to the following questions:

1) Do you think your response is creative? Why or why not?

2) Do you think this task could be a (good) measure of creativity? Why or why not?

Entry \#4: Write a haiku about the artist you chose for your project.

After completing your poem, on the next page, consider and respond to the following questions:

1) Who is your artist?

2) How did you complete this task? What did you do first, next, and so on?

Did you follow Wallas' steps for the creative process? How so? (be sure to identify the steps you followed and how you followed them)

Entry \#5: On a full page draw a symbolic representation of a creative person. Use metaphors, analogies and associations.

After completing your drawing, on the next page, consider and respond to the following questions:

1) Was your drawing inspired by a particular creative person? If yes, who? Why? If the drawing was not inspired by a particular person, what personal characteristics have you depicted?

2) Was using metaphors, analogies and associations useful in drawing the representation of a creative person? Why? Why not?

Entry \#6: Draw, paint, color (use line, shape, color) on a full page in your journal to represent how you are feeling while listening to your favorite song.

After completing your drawing, on the next page, consider and respond to the following questions:

1) Which song did you listen to for this assignment? Identify the song and artist.

2) Did you notice any of the following while you were working on this task? Distorted sense of time - for example, not sure how long you were working ("lost track of time"); enjoyment of task while doing it; intense concentration; feeling challenged in a good way? If yes, which? How so?

3) Have you ever experienced any of these things while completing a task before? When?

Entry \#7: While playing music that you do not like at a loud volume, write a poem or very short story with the title "2983." (Note: time yourself; stop after 5minutes!).

After completing your writing, on the next page, consider and respond to the following questions:

1) Which song(s) did you listen to for this assignment? Identify the song(s) and $\operatorname{artist}(\mathrm{s})$. 
2) Did you find this assignment to be easy or difficult to do? How so?

3) Do you think your product is creative? Why or why not?

Entry \#8: Your task is to go to a gallery or art museum exhibit, attend a concert, or attend a theatrical production. Be sure to paste some evidence of your attendance, whether it is a ticket stub, flyer, or program. Some suggestions include art galleries on campus, and campus concerts and theatrical productions. After the visit, consider and discuss the following:

1) What is the title of the work you attended? In what domain was the work? (music, painting, etc.)

2) Did you find the work creative? Why or why not? Did you like it? Why or why not?

3) Do you have any training in this domain? Do you do work in this domain, whether professionally, academically, or as a hobby?

Have you visited a work in this domain before, or was this a new experience for you? What was it like to be an observer of artworks? (did you find completing this assignment to be difficult, easy, or some of both? Why? Did you find the visit to be inspiring or more like a chore?).

Entry \#9: Design a Tattoo for yourself.

After completing your drawing, on the next page, consider and respond to the following questions:

1) What did you do and why? Where would you put it?

2) How do you think your experiences in your environments (social, cultural and historical influences) influenced your choices?

\section{Entry \#10: Final Creative Project entries.}

1) Evidence of notes/draft of final project; critique forms (I should be able to see your progress.)

2) Reflection on the completion of the project (this will be a preparation for your presentation). Discuss the following:

a. Did you complete a children's book, comic, poem, spoken words performance or write a creative essay? Who is your artist/scientist/inventor? Which course concept did you apply to your artist/scientist/inventor in your project? Why this concept and why did you use this course concept in this way?

b. Consider Wallas' stage model and the Geneplore model of the creative process. Which best fits your process for the project? How so? (be sure to identify the steps you followed and how you followed them; also indicate if there is a step you didn't follow)

c. How did the guidelines for the project affect your process and product? Did the guidelines seem "constraining?" Do you think the guidelines enhanced your creativity? Why or why not?

d. How did knowing that you were going to present your creative project to an audience impact your process and/or product?

e. What was your experience of the critique? Was it helpful or not, and how so? How did it affect your progress?

f. What makes your project an effective, creative product for this assignment? What are your thoughts about your final product and the project overall? 


\section{Entry \#11: Final journal reflections.}

1) Discuss the following (do NOT look at your writing from the start of the semester):

2) What is creativity?

3) How do you determine whether something is creative? What criteria do you use?

4) Now, look at your writing about creativity and its criteria at the start of the semester.

a. Have you thoughts about what is creative changed since the beginning of the semester? If yes, how so? If no, why not?

b. Have your thoughts about creativity changed since the beginning of the semester? If yes, how so? If no, why not?

5) Reflect on your motivation to complete the assignments. Did you find that you spent extra time on some journal assignments? Why or why not? Which? Why? (consider the role of intrinsic and extrinsic motivation)

6) Consider and write about the course material and overall course, including the readings, lecture material and experiences, and assignments. Discuss your overall experience of the course so far. This can include what you found interesting, inspiring, troubling, surprising, and/or challenging. Did you learn what you hoped to learn at the start of the semester?

Table 2. Descriptions and learning objectives for Creative Project and its accompanying assignments.

\section{Creative Project}

This project requires you to choose a creative person, influential artist, scientist or inventor (e.g., painter, sculptor, writer, musician, psychologist, chemist, etc.), and complete a creative project (you will have a choice of doing a children's book, comic strip(s), a poem/lyrics or spoken word performance, or a creative essay) based on the application of course material to this artist/scientist/inventor.

Project Learning Objectives: This project is intended to provide you with an experiential learning activity that allows you to complete a large-scale creative work while critically applying course concepts to personal creativity (to your work, creative process, and to yourself as a creative person, especially as you complete an atypical task). By requiring you to consider a different perspective and use non-technical language, this project allows you to explain aspect of creativity to people who have not taken this course. This project allows you to:

- Critically consider course material in application to a specific artist/scientist/ inventor.

- Further learn about an artist/scientist/inventor, domain, and course concept.

- Practice literature review, synthesis, application, critical thinking, and communication skills.

- Increase and assess your conceptual understandings of course material. 


\section{Assignment 1: Choice of Creator}

\section{Objectives:}

- Direct you into the mental state required to complete the creative project.

- Help you consider what you know and do not know about the artist/scientist/ inventor that you selected;

- Begin the information gathering needed to complete the tasks.

- Help you progress in a timely manner; and to be sure that you have chosen an appropriate artist/scientist/inventor and references.

Description: Choose an artist/scientist/inventor for whom you can easily obtain biographical or autobiographical information. It will be easier for you to focus on Big-C creator, beginning from around 1800, than to choose a contemporary artist/scientist/ inventor about whom not much have been written yet. You may face a similar obstacle when choosing someone who is a Pro-C creator - widely cited and recognized, but with not much bibliographical information about them. Semester in and semester out, I have seen students who chose an artist on which little is written (including people like Banksy who deliberately do not share information about themselves) and had difficulties adequately completing the assignments; some of them had to change their person close to the assignment deadline! To avoid this, be sure to read the project requirements before choosing your creative person to ensure you will have adequate information.

\section{Assignment 2: Application of course material to creator}

\section{Objectives:}

- Continue preparations for the creative project; to select (if necessary) and elaborate on the information listed in Assignment 1

- Gather information about your artist/scientist/inventor in relation to course concepts

- Critically consider course material in application to a specific artist/scientist/ inventor

- Allow for further learning about an artist/scientist/inventor, domain, and course concept

- Consider which concept may work best for your creative project

- Help you progress in a timely manner; and to get feedback about your concepttual understanding.

Description: A) Present your artist/scientist/inventor and two course concepts of your choice that you intend to apply to your creator. The presentation of your creator can be adapted from the introduction/accomplishments paragraph you wrote for Assignment 1. B) Discuss what the course material say about each of the two course concepts you chose (e.g., how is it defined, what does theory and/or research say about them)? You may use the textbook, class notes, or both for this. I encourage you to look up primary sources cited in the textbook and during the lectures. C) Discuss how your artist/scientist/ 
inventor display each concept. Use and expand upon, if possible, the evidence you collected for the Assignment 1 - that is the list of 4 psychological factors. Remember to include information from your library reference with the APA style citation that discusses what the artist/scientist/inventor has said or done that relates to the concept. Be sure to provide the citations and references for course material and the information about your artist/scientist/inventor! D) Answer the following questions: Is your artist/scientist/ inventor consistent or inconsistent (or both) with course material related to each concept, and why he or she is or isn't; discuss the way he or she is consisted or inconsistent (or both) with the concepts, provide clear arguments that are backed up with evidence from your readings on $\mathrm{a} / \mathrm{s} / \mathrm{i}$ and on the course concepts.

\section{Assignment 3: Final Creative Project}

\section{Objectives:}

- Provide an experiential learning activity that allows you to complete a larger scale creative work and critically apply course concepts to personal creativity (to your work, creative process, and to yourself as a creative person, especially as you complete an atypical task).

- Critically consider course material in application to a specific artist/scientist/ inventor; allow for further learning about an artist/scientist/inventor, domain, and course concept; practice literature review, synthesis, application, critical thinking, and communication skills.

- Increase and assess your conceptual understandings of course material by explaining some aspect of creativity to people who have not had this course (by considering a different perspective and non-technical language).

- Practice oral presentation skills

Description: Choose one of the project options (children's book, comic strip(s), poem/lyrics/spoken word performance, or creative essay). Please keep in mind that not only will you be working on this project for a large portion of the semester, you will also be presenting your project to the class. Be sure to choose a project with which you will be comfortable. Have fun with this project - see what you can do! I encourage you to consider completing work that can be used in a portfolio to represent your work from this school, as well as this class. You will find it easier to think about this project after you have completed the preparation tasks, so if you find yourself overwhelmed, take it one step at a time!! Please see me if you find that you are feeling stuck and not sure how to proceed.

Option 1: Create a children's book that includes your artist/scientist/inventor and a course concept, with narrative and illustrations. Your task is to explain some aspect of this person's creativity to children in a simple, visually, and conceptually interesting way, with easy to read narrative that is appropriate for children in the preschool or school years (ages 3-10; grades preschool-5). The book must demonstrate understanding of a course concept (it should illustrate an application). You may complete the book in your journal or create a book outside of the journal. I highly recommend going to the library and looking at samples of children's books as part of your preparation. Try to create a work that is more than a simple recounting of the course concept in the artist/scientist/inventor's life! 
Option 2: Create a newspaper comic strip(s) that includes your artist/scientist/inventor and a course concept, with captions and drawings. Your task is to explain some aspect of this person's creativity in a simple, visually and conceptually interesting way, using a comic-style (ideally with some type of humor), with easy to read captions. The comic strip(s) must demonstrate understanding of a course concept (it should illustrate an application). Please note that content should be appropriate to be printed in a local newspaper, so choose your words and drawings carefully. You may complete the comic(s) in your journal or create a book outside of the journal. I highly recommend going to the library and looking at samples of newspaper or magazine comics (or comic books) as part of your preparation. Try to create a work that is more than a simple recounting of the course concept in the artist/scientist/inventor's life!

Option 3: Write a poem, spoken word performance, or lyrics that includes your artist/ scientist/inventor and a course concept. Your task is to explain some aspect of this person's creativity in a simple and conceptually interesting way, using poetry and performance. The poem(s) must demonstrate understanding of a course concept (it should illustrate an application). Please note that content of your poetry or lyrics should be appropriate for your target audience. Should you write a poem or song in the style of a children's author, the language should be suitable for children. I highly recommend examining examples of poems, lyrics or spoken word performances as part of your preparation. Try to create a work that is more than a simple recounting of the course concept in the artist/scientist/inventor's life!

Option 4: Write a creative essay on any topic from the perspective of your artist/ scientist/inventor. Your essay must demonstrate understanding of a course concept in some way (it should illustrate an application), whether via the essay topic, or via examples used to explore the essay topic. You must write an essay that is novel and appropriate for addressing your topic. I highly recommend examining examples of creative essays and creative non-fiction as part of your preparation. Try to create a work that is more than a simple recounting of the course concept in the artist/scientist/inventor's life!

\section{Additional Assignment 3 Components:}

\section{Critique Day}

Description: You are required to bring a draft of your project to class for discussion and review. It should include all required components so that you can get adequate feedback. You should use the journal to draw and write your drafts and keep your notes for your project. I will look for these (the presence of your notes and drafts will be part of your journal grade).

\section{Final Project Presentations}

Description: As (will be) discussed in class, sharing the creative work with others is an important part of the creative process and product. You will be asked to share your project with the class and discuss what you did and why. Your presentation should be no longer than 8 minutes (students who go over will be cut off, so be sure to do a runthrough). 
Table 3. Layout of course thematic units and creative problem-solving activities. Adapted for the creative project from Sawyer, K. (2013). Zig Zag: The surprising path to greater creativity. CA: Jossey-Bass.

\begin{tabular}{|c|c|c|}
\hline \multicolumn{3}{|c|}{ Creative Process and Creative Problem-Solving Workshops } \\
\hline Thematic Unit & Activity & $\begin{array}{c}\text { Creative Project } \\
\text { Assignment }\end{array}$ \\
\hline $\begin{array}{l}\text { Creative Problem } \\
\text { Solving \& Prob- } \\
\text { lem Finding }\end{array}$ & $\begin{array}{l}\text { Pick the worst idea: What would be the worst } \\
\text { creative project for this project type for this } \\
\text { course? What would a good, creative project } \\
\text { look like: Children's book; Comic; Poem/lyrics; } \\
\text { Creative essay? }\end{array}$ & $\begin{array}{l}\text { Preparing for } \\
\text { Assignment } 1\end{array}$ \\
\hline $\begin{array}{l}\text { Acquiring } \\
\text { Knowledge: } \\
\text { Deliberate } \\
\text { Practices \& Skills; } \\
\text { Deep Learning \& } \\
\text { Mastering Content }\end{array}$ & $\begin{array}{l}\text { Acquire knowledge for project and Branch Out: } \\
\text { What is the most relevant information needed } \\
\text { to complete this project? } \\
\text { What skills do you need to develop and practice } \\
\text { to complete this project? } \\
\text { Branch out: Identify at least one topic that is } \\
\text { seemingly somewhat or distantly related to } \\
\text { your project that may help you to complete it. } \\
\text { What will you do to acquire this knowledge? } \\
\text { What will you read? } \\
\text { What will you research? Other? }\end{array}$ & $\begin{array}{l}\text { Assignment 1: } \\
\text { Choose Creator } \\
\text { Due; } \\
\text { Preparing for } \\
\text { Assignment } 2\end{array}$ \\
\hline $\begin{array}{l}\text { Gathering } \\
\text { Information: } \\
\text { Attentiveness, } \\
\text { Mindfulness, } \\
\text { Observation, } \\
\text { Patterns Search }\end{array}$ & $\begin{array}{l}\text { Switch perspectives: How would you see and } \\
\text { think about this problem differently if you were } \\
\text { your artist/scientist/inventor? }\end{array}$ & $\begin{array}{l}\text { Preparing for } \\
\text { Assignment } 2 \& 3\end{array}$ \\
\hline $\begin{array}{l}\text { Incubation: Types } \\
\text { of Breaks, Play- } \\
\text { fulness }\end{array}$ & $\begin{array}{l}\text { Follow the long arrow: Wherever you are } \\
\text { sitting, envision a straight, invisible arrow } \\
\text { shooting horizontally away from you. Imagine } \\
\text { that it keeps going for at least a mile, parallel to } \\
\text { the ground. Imagine moving out along that line } \\
\text { very slowly. As you go, identify all of the objects } \\
\text { you pass through. Take your time, your arrow } \\
\text { flies very slowly. Make sure to imagine every- } \\
\text { thing it will pass through. At the end of a mile, } \\
\text { envision exactly where your arrow is when it } \\
\text { drops to the ground. What's around the arrow? } \\
\text { Where is it resting, on what kind of ground? } \\
\text { What do you hear and smell and see? }\end{array}$ & $\begin{array}{l}\text { Preparing for } \\
\text { Assignment } 2 \& 3\end{array}$ \\
\hline
\end{tabular}


Generate ideas: In what ways could you incorporate your artist/scientist/inventor into your

Generating Ideas: Generating Ideas through Insight and Incremental Approach project? List as many ways as you can during the allotted time and be specific.

Consider fluency, originality, flexibility, and elaboration.

Did you think of any ideas during discussion to

Preparing for

Assignment 2 \& 3 add to your list? Any ideas to bor-

row/adapt/build on?

Fuse: Make remote associations

Refer to your list of ideas for including your artist/scientist/inventor

Combining Ideas: Number them and

Using Associa-

tions, Metaphors, and Analogies use a random number generator to select two numbers within the range of numbers of ideas you have and combine the two ideas selected. Discuss: Describe your combination to the group. How could this inspire your approach to your project? Any suggestions?
Preparing for

Assignment 2 \& 3

Define greatness: Make criteria explicit. What are the specific characteristics of a great

Selecting Ideas: Evaluation and Creativity, Using Criteria for Evaluating Ideas creative project idea? What will you look for when choosing ideas? Arrange criteria along dimensions: 1) Highly feasible and useful to Difficult and of unclear use; 2) Normal and

Assignment 2: Application Paper Due ordinary ideas to Original and breakthrough ideas. Arrange ideas along the dimensions

Externalizing
Ideas: Sharing
Draft of the Final
Project with
Classmates during
Critique Day

Project activity: Explain your project to classmates; solicit their ideas and advise.
Full Draft of

Creative Project

Due 